\title{
BANATUL, TEMĂ LIRICĂ ÎN LITERATURA ROMÂNĂ DIN VOIVODINA
}

\author{
BANAT AS A LYRIC THEME IN ROMANIAN \\ LITERATURE \\ IN VOJVODINA
}

\author{
Brândușa JUICĂ \\ Universitatea din Belgrad, Facultatea de Învățători/ University of Belgrade, Teacher \\ Education Faculty \\ e-mail: zujkab@yahoo.com \\ Virginia POPOVIĆ \\ Universitatea din Novi Sad, Facultatea de Filozofie/ University of Novi Sad, Faculty \\ of Philosophy \\ e-mail: popovic.virdjinija@ff.uns.ac.rs
}

\section{Marinel NEGRU}

Universitatea din Belgrad, Facultatea de Învățători/ University of Belgrade, Teacher

Education Faculty

e-mail: Marinel.Negru@uf.bg.ac.rs

\begin{abstract}
In Romanian literature in Vojvodina, Republic of Serbia, poetry is the favourite genre of writers, especially when it comes to the second half of the twentieth century. Among the lyrical themes often explored by the authors who wrote their texts in Romanian, the theme of the homeland of yesterday and today, occupied a privileged place. Natural beauty, childhood images, loved ones, customs and traditions, educational aspects, social coexistence, the multicultural specificity have also quite often become literary topics. This article reveals some lyrical experiences in which the homeland - Banat, is in the focus of some poets, belonging to different literary generations. Their writings are according to the feelings of nostalgia, alienation, wanting to return to the past through recollection or dreams. On the other hand, in addition to daydreams of their home and self-searches, we are drawn to the approaches to these topics that place Romanian literature in its own right, at the confluence of the two European literatures, Romanian and Serbian. The lyrical creations that present such characteristics are included both in author's collections of works as well as on the pages of the magazine ,Lumina", the symbolic publication of Romanian culture in the former Yugoslavia and present-day Serbia.
\end{abstract}

Keywords: literature; Romanian poetry; homeland; trends. 
Voivodina, provincie autonomă din Serbia de astăzi, reprezintă unul dintre spațiile din afara granițelor țării în care locuiește una dintre cele mai numeroase populații de români. $\mathrm{Cu}$ un puternic caracter multietnic, Voivodina recunoaște mai multe limbi oficiale, printre care și limba română. Într-un asemenea context favorabil, pe acest teritoriu s-a înregistrat o evoluție ireversibilă a literaturii române abia după cel de-al Doilea Război Mondial, când s-au pus bazele istorice și spirituale ale minorității românești de aici, precum afirmă exegeții care s-au ocupat cu cercetarea dezvoltării diacronice a acesteia. Literatura română din Voivodina este o literatură tânără care și-a creat fizionomia proprie în a doua jumătate a secolului trecut, când a păşit pragul instituționalizării odată cu înființarea instituțiilor care au sprijinit apariția primelor cărți în limba română. Importante în acest sens sunt Editura Libertatea (1945) și revista de cultură și literatură „Lumina” (1947), publicație unde au debutat aproape toți poeții români din Voivodina. Apariția acestei reviste literare a fost facilitată și de apariția, în interbelic, a periodicelor românești cum ar fi „Opinca” (1918-1919), „Graiul românesc” (1923-1926), „Foaia Poporului Român” (1936-1938) și „Biruința” (19381939), „Calendarul Poporului” (1922-1925), „Nădejdea” (1927-1944), precum a fost influențată, mai ales, de caracterul multietnic și multilingvistic pe care Voivodina 1-a avut, neîntrerupt, în ultimele două secole și jumătate. Fenomenul literar românesc din Voivodina a evoluat de-a lungul anilor la confluența dintre literatura română și sârbă, cu influențe din literaturile fostei Iugoslavii și din literaturile comunităților conviețuitoare, dobândind autenticitate prin stilul auctorial, realitatea socio-culturală și lingvistică în care s-au format și afirmat scriitorii de limbă română. Prin verticalitatea unora dintre acești autori, literatura în limba română a depășit statutul de literatură minoritară. $\mathrm{O}$ mare parte dintre poeții români din Voivodina au abordat teme vizând Banatul sârbesc, locul unde s-au născut și unde și-au petrecut, dacă nu întreaga viață, cel puțin o parte importantă din aceasta. Poezia despre Banat este numită de poetul Ioan Baba ,cântec de dor despre o țară” (Baba, 2006: 17). Spațiul multietnic al Banatului, nostalgia faţă de plaiurile natale și dragostea față de toposurile „de pustă” (regiunea de șes) și „de codru” (zona din jurul dealului Vârșețului unde trăiește cea mai mare populație de români din Serbia de Nord) sunt atotprezente în memoria afectivă a poetului, reînviate în versuri pline de lumină și sensibilitate și imagini inedite scrise într-o limbă frumoasă, presărată pe alocuri cu „bănățenisme”, pentru a reda culoare și frumusețe locurilor descrise.

„Majoritatea scriitorilor din Voivodina s-au născut în Banat iar ținutul lor natal și dragostea față de el se reflectă, în opera lor, transformând-o 
în una originală, autentică [...]. Scriitorul din Voivodina a depășit statutul de scriitor local sau regional, valoarea poeziei este una europeană în continuă transformare și noi conotații” (Popović, 2017: 137).

Considerăm anul 1946 ca fiind momentul nașterii primelor cărți de beletristică în limba română din fosta Iugoslavie, adică momentul în care „scriitorii s-au desprins din masa de intelectuali ,înșcolați”, în țară sau în România, și au format o elită cărturărească incontestabilă. „În opoziție cu exegeții care susțin că această literatură a evoluat pe cont propriu, fiind necesară mai întâi formarea unor instituții care să o promoveze, putem afirma că ea a fost, de la început, ,,sensibilă” la influențele modelelor și mișcărilor literare europene cu care s-a putut identifica" (Popović, 2019: 106).

În literatura română din Voivodina, poezia s-a bucurat de o atenţie sporită din partea scriitorilor români/ de limbă română. În evoluția sa, discursul liric a traversat etape diferite care i-au conturat un destin ascensional. Dacă fondatorii mișcării literare în limba română s-au acomodat cadrului ideologic specific lumii noi care s-a instaurat pe la mijlocul secolului trecut, următoarele generații literare se atașează tendințelor progresiste, reformelor literare românești, sârbești, europene. Apelând la modalităti și motive autohtone sau născute în lume, poezia de azi transmite frământările acute ale realității în care poetul își desăvârșește actul creativ și intră în dialog direct cu depărtările, tocmai pentru a-și consolida identitatea.

„Tematica multiplă, bogată și variată, îmbinarea elementelor limbii literare $\mathrm{cu}$ cele dialectale, diferite experiențe literare, uneori tendențioase, alteori moralizatoare, transmutația de la sat la oraș, diferite opoziții şi planuri inversate, precum și investigația psihologică, limbajul intelectualist, fraza complicată de conveniență, acțiuni stereotipe, toate aceste caracteristici antrenează cititorul voivodinean la o lectură captivantă" (Popović, 2019: 106.

Lirismul românesc voivodinean din ultimul pătrar al secolului al XX-lea a fost supus investigațiilor de specialitate, care în ultimele decenii s-au intensificat, materializându-se în studii, teze de doctorat, volume și antologii de critică literară și antropologie culturală. Exegezele critice care au apărut atât în Serbia, cât și în România, asigură, pe lângă dimensiunile valorice, vizibilitatea discursului liric și mersul înainte al creaţiei poetice.

Între temele lirice des abordate de autorii care și-au scris opera în limba română, ținutul natal, de ieri și de azi, a ocupat un loc privilegiat. Frumusețile naturii, imagini din copilărie, oameni, obiceiuri și tradiții, aspecte educaționale, conviețuirea socială, specificul multicultural au devenit adesea subiecte literare. Articolul de față relevă câteva experiențe lirice în 
care ținutul natal - Banatul - reprezintă preocuparea unor poeți, apartenenți ai diferitelor generații literare. Creațiile acestora se modelează în conformitate cu trăirea sentimentelor de nostalgie, înstrăinare, revenire prin rememorare sau vis la vremurile și locurile de altădată care oferă spațiu de refugiu și adăpost. Se conturează apoi și imaginea etnicului român, credincios simbolurilor identitare veșnicite în casa părintească. Pe de altă parte, pe lângă reveriile de acasă și căutările de sine, ne atrag atenția demersurile scriitoricești care așază literatura română în plan propriu, la confluența celor două literaturi europene, română și sârbă. Creațiile lirice care prezintă astfel de caracteristici sunt cuprinse atât în volume de autor, cât și în paginile revistei „Lumina”", publicația simbol a culturii românilor din fosta Iugoslavie și Serbia de astăzi. Indiferent de generația literară căreia aparține ori de locul în care își duce viața de zi cu zi, pentru creatorul versului românesc din Voivodina ,abordarea literară a rădăcinilor din spaţiul Panoniei este o conștiință de sine și un meritorism viabil al poeților, constituind un model cultural de identificare etnică.” (Baba, 2006: 17). Ioan Baba, cunoscând personal o mare parte dintre poeții născuți în Banatul sârbesc și bun cunoscător al întregii operei lor lirice, a desprins atent din opera lor versurile care cântă frumusețile plaiurilor bănățene, publicându-le în antologia de poezie lirică Banatul în memoria clipei la Editura Libertatea din Panciova. Autorul a început cu poezia română care recurge la modalități clasice și s-a orientat, treptat, spre poezia care cultivă limbajul modern și postmodern, reușind astfel să-i prezinte publicului toate colțurile Banatului, prin versuri care aduc în atenție cele mai amănunte îndeletniciri și sentimente ale omului bănățean, cu obiceiurile, ritualurile și tradițiile lui, munca pe câmp, aurul lanurilor de grâu și satele românești îmbrăcate în hainele celor patru anotimpuri. De la blândețea peisajului bănățean, care este tema majoră a întregii generații cincizeciste din Banat, trecând peste versurile specifice anilor șaizeci, celebrând socialismul cu imagini din universul rural, peste poezia - erotică, de inspirație folclorică și de tip maiakovskian, autorul acestui almanah panoramic a reușit să desprindă zbaterile, nădejdile și năzuințele țăranului, mai ales în cele în care evocă cărări și văi natale românești, unde poetul bănățean se lasă, de cele mai multe ori, copleșit de un lirism cald și duios. La unii poeți, nostalgia lumii rememorate autobiografic nu determină viziunea, ci tensiunea care este iminentă în psihologia colectivă în urma unei evoluții sociale. Poetul bănățean recurge adesea la amintire sau la vis încât din pana lui se nasc versuri pline de dor și melancolie.

\footnotetext{
${ }^{1}$ Revista „Lumina” a fost fondată în ziua de 12 ianuarie 1947 la Vârșeț de Cercul literar Lumina, al cărui succesor este Cercul Lumina - Honoris Causa, fondat la 11 august 2006, la Panciova. Revista apare și astăzi, sub egida Casei de Editură și Presă Libertatea din Panciova.
} 
În peisajului rural, poetul român bănățean descoperă viețuirea cotidiană într-o lume plină de mistere, cu forțe ascunsă ale tradițiilor moștenite de la predecesori, în care se declanșează un șir lung de căutări printre dogme, teorii și iluzii asupra adevărului, asupra esenței vieții. Visul e, pentru poet, o fereastră spre lumină, care, odată întrerupt, permite unei noi zile să înceapă o nouă căutare spre necunoscut. Toposurile ontologice bănățene descoperă, în versuri, un spațiu unic pe acest pământ unde poetul se găsește ,acasă”, unde trăiește o copilărie paradisiacă și unde simte primele sentimente erotice. Gândurile spre zilele trecute, spre lumea cunoscută cândva declanșează în suflet și în memorie o nesiguranță, semn că anii trec ireversibil, iar amintirile se șterg odată cu trecerea lor. Râurile bănățene, dealul Vârșețului, satele de la pustă satele de la codru, pădurile și dunele de nisip, câmpiile cu verdeață și lanurile de grâu, miriștea fraged arată și țăranul ostenit, cu patimile și preferințele lui, sunt descrise de poeții tradiţionaliști bănățeni.

Pornind de la prima generație de scriitori români care s-au format în contextul socio-cultural iugoslav al anilor cincizeci, în demersul de faţă, amintim numele lui Ion Bălan (1925-1976), un scriitor paradigmatic datorită operei eterogene, precum și a influenţei sale asupra spaţiului cultural românesc din Iugoslavia, din a doua jumătate a secolului trecut. Ca prozator și poet, drumul lui Ion Bălan ,a pornit de la sat și a revenit în permanență la sat, iar statutul scriitorului a fost acela al dezrădăcinatului care caută puncte de reper în geografia sufletească a copilăriei ..." (Juică, 2012: 84). Încă de la primul său volum, Cântecul satului meu (1947), cu tematică imnică și lipsit de lirism, autorul aduce în prim plan toposul natal al cărui simbol este Mărul - Jabuka (în limba sârbă), denumirea veche a localităţii natale. Scriitor de obediență tradiționalistă, încadrat cu trup și suflet în transformările revoluționare ale vremii, Ion Bălan a evocat satul copilăriei în vers duios și nostalgic, fără a accepta inovațiile, fiind însă ademenit de schimbările din natură, și prețuind moștenirile înaintașilor - preocupându-se de poezia anotimpurilor:

„De câte ori a nins/ în zile reci de iarnă,/ un singur fulg n-am prins/ din zare să se-aștearnă/ în palma strânsă ciob-/ de nerăbdare plin-/ să-mi fie tăcerii rob/ și floarea de băgrin, surâs de aromă vie/ ceadoarme și-nvie./" (Zi de iarnă) (Bălan, 1912: 56).

Sub influența atmosferei literare din anii șaptezeci, în opera scriitorului Ion Bălan se întrevăd formule noi și, în acest context, poezia dedicată copilăriei și satului natal dobândește „o orchestrație metaforică transpusă în melos romanțios" (Popa, 1997: 53). Privind îndeaproape această poezie, exegetul Milan Uzelac o definește ca pe ,un amestec de trăire și visare, o 
întrepătrundere între real și posibil, între ceea ce s-a întâmplat de nenumărate ori, iar tocmai ce părea cunoscut este, în esență, izvorul necunoscutului" (Uzelac, 1985). Un exemplu ar putea fi și următoarele versuri:

\begin{abstract}
„Aici, în Măru, seara, iarăși vin/ să desfir, comoară minunată,/ Poveste de-nceput,/ povestea cu Truia/ (cel ce, după cum se spune,/ satului a pus temei)/ și ca-ntotdeauna mă-ntreb/ dacă-i mai știu sătenii mei,/ ori eu visez mereu?" (Aici, în Măru, seara, iarăși vin) (Bălan în Baba, 2017: 94).
\end{abstract}

Radu Flora (1922-1989), om de știință, profesor universitar, poet, prozator, eseist, istoric și critic literar, lingvist și dialectolog, a fost unul dintre fondatorii și animatorii vieții culturale și literare a românilor din Voivodina. A lăsat moștenire o operă eterogenă vastă, apreciată de numeroși critici și istorici literari și care este îndelung cercetată și în prezent, în special în cadrul simpozioanelor internaționale anuale - „Memorial Radu Flora”, organizate de Societatea de Limba Română din Voivodina. „S-a bucurat de un prestigiu care n-a fost clintit, în timp fiind recunoscut ca principal autor al scoaterii din anonimat cultural a conaționalilor săi." (Agache, 2010: 80). În literatura românilor din Iugoslavia, Radu Flora a susținut cu fermitate direcția tradiționalistă. A fost perceput, însă,

„ca un călător solitar prin spațiile întinse ale cunoașterii, reîntorcânduse spre satul-experiență, locul fierbinte și privilegiat al amintirii și reveriei într-un continuu dialog cu lumea, încărcat de straturi livrești, dar străbătut și de o vibrantă undă folclorică.” (Lăzăreanu, Păun, 1995: VIII).

În cadrul ideologic permis, apoi în contextul înnoirilor din anii şaptezeci, a scris pagini de proză și versuri memorabile despre plaiurile bănățene înveșmântate în tradiția multiculturală și rostirea plurilingvă. Pentru Radu Flora satul natal a însemnat locul de refugiu în care și-a găsit echilibrul, liniștea, visele, confirmă deseori copiii săi Steluța și Viorel Flora. Prin intermediul rememorării nostalgice, poetul se apropie de anii copilăriei, construind imagini lirice documentare, care vorbesc de buni și străbuni creatorii de ,istorii aninate-n cadre ilustre” (Portrete familiale), de dărnicia naturii și nevinovăția vârstei, toate îmbrăcate ,într-o aură de puritate necesară renașterii sufletului reveur-ului solitar ajuns la maturitatea înţelepciunii" (Agache, 2010: 91). Spre argumentare ne folosim și de cuvintele poetului:

„Satul, pitit în umbră de duzi și salcâmi,/ doinește - un cântec de jale răsucindu-și vaierul./ Un greier înțeapă melodic tihna nopții./ O stea căzând străpunge aerul./ Ecoul unui lătrat de câini vrea s-alunge/ 
stereofonia din unghere./ Peste ani le-ascult și le pricep,/ Și cu mintea de adult, îmi par astăzi/ basme ale copilăriei/ tivite cu tăceri împlinite şi sarcasme”. (Nostalgia orizontului apus) (Bălan în Lăzăreanu, Păun, 1995: 10).

În avântul reformei poetice, autorul este preocupat de aspecte existențiale, exprimându-și trăirile în versuri intime privitoare la efemeritatea vieții, în poezii peisagistice care nu cuprind doar fizionomia naturii, ci și opinia poetului față de viață și rostul pământean. Revenind totodată la motivele satului bănățean rămase depozitate în sufletul copilului de ieri, poetul scrie următoarele versuri:

„În satul natal, pe străzile amintirii,/ cumpăna fântânii, ca o săgeată frântă, împunge cerul// și șesul întins este furnicar de visuri/ crestat, ca-n hărțile școlare, cu echerul,// în satul natal și azi, în dricul zilei,/ babele cârtesc și copiii vin, gălăgioși de la școală./ Doar eu lipsesc, nemotivat, din peisaj/ și absența mi se pare neînțeleasă, ca o tăinuită boală” (Absența din peisaj) (Flora în Baba, 20177: 92).

Înălţat spiritual eul liric alungă contemplarea, însă noua stare de fapt nu atenuează sentimentul dezrădăcinării:

„Mi-am lăsat ca ieri satul dintre dealuri/Şi-am plecat pe drumul făroprire/ Mărginit de schilavi duzi bătrâni// Ca un râu ce-n truda-i de-a învinge malul/ Îşi duce târând spre noi şi noi peisaje valul/ De mult mă poartă paşii tot mai obosiţi./Am plecat ca ieri pe drum făr-oprire/" (Mi-am lăsat ca ieri satul dintre dealuri) (Bălan în Baba, 2017, 98).

În contextul poeziilor dedicate plaiurilor bănățene, pot fi citate și alte titluri, precum: Aur, Curge râul, Peisaj în clar de lună, Peisaj de pustă, Iarna în satul natal, Absență în peisaj.

Traversând primul deceniu din a doua jumătate a secolului al XX-lea, evoluția scrisului românesc din Voivodina a fost influențată de atmosfera literară iugoslavă, care era antrenată într-un aprig proces al deschiderilor spre noile tendințe literare europene (Juica, 2012: 136), precum și de debutul generației lui Nichita Stănescu. În acest context s-a pregătit lansarea noilor generații de scriitori. Primul care a intrat în conflict cu generația vârstnică a fost tânărul poet Ion Miloș (1930-2015). În urma publicării eseului Ce-i de făcut? (în revista „Lumina”, nr. 6/1957; nr. 1/1958), primul nostru dizident ${ }^{2}$ a pornit pe calea exilului și s-a stabilit în Suedia. A devenit

\footnotetext{
2 În articolul Poezia de dincolo de cărți, Slavco Almăjan consemna următoarele: „Ion Miloș a fost primul nostru dizident înainte de dizidenți și primul intelectual român de pe aceste
} 
„un poet de o frapantă originalitate căruia ursitoarele i-au hărăzit premise din cele mai rare: să se nască român, fiu de țărani din Banatul Sârbesc, să scrie poezii originale în patru limbi, să se afirme, în sfârșit, ca un novator și un poet modern în limba părinților săi, pe care o manevrează magistral..." (Miloș în Cioculescu, 1984: 8).

Așa îl prezenta publicului cititor, în anul 1984, Șerban Cioculescu, patriarhul criticii românești de atunci, în Cuvânt înainte la volumul Nunți boreale, care a apărut la prestigioasă editură bucureșteană Cartea Românească, în anul 1984. De la debutul editorial (Vârșeț, 1953) și până la sfârșitul vieții, în demersul liric a adunat stiluri diferite, marcate de modernism sau de inedit, care îl așază pe Ion Miloș în universalitatea spiritului românesc. La acestea, am mai adăuga și faptul că numeroasele traduceri prin care Ion Miloș i-a făcut cunoscuți în spațiul cultural european pe mai marii și mai micii culturii noastre naționale, îi asigură un loc însemnat între traducătorii de seamă, între „eroii unui travaliu care n-a fost niciodată răsplătit la adevărata lui valoare" (Ungureanu, 2005: 210). În lumea exilului, poetul a trăit și a murit tot de atâtea ori cu dorul locurilor natale, pe care le-a revăzut abia în anul 1989. Amintirile le-a purtat cu el printre nămeții nordului ${ }^{3}$, veșnicindu-le în vers, fără a-și uita rădăcinile: „Eu, fiul Laviei și al lui Iosif/ Români minoritari/ Din Banatul sârbesc" (Printre nămeții Nordului) (Miloș, 2012: 112).

Tristețile izvorâte din rătăcirile vrute și nevrute ale veșnicului dezrădăcinat nu-și găsesc sfârș̦itul nici la reîntâlnirea poetului cu ținutul natal. Mai mult, îl confruntă cu desfigurarea chipului și a desprinderii din peisaj: „Am ajuns la fântână/ Și plâng/ Nu-mi mai văd chipul în apă/ Vin din dragoste/ Și oamenii nu mă cunosc/ Pielea mea e vânătă de mușcături de şarpe..." (În trei limbi) (Miloș în Lăzăreanu, Păun, 1995: 42).

Privit $\mathrm{cu}$ atenție și apreciat de elita criticii literare, pentru urmele pregnante imprimate în solul literaturii şi imagologiei sau al altor domenii artistice, Slavco Almăjan (1940), liderul celei de-a doua generații de scriitori români, numită de mijloc, a marcat „o răscruce în evoluția literaturii române din Voivodina." (Agache, 2010: 199). Colindând labirinturi rotative, nutrindu-și fiorii cu simboluri vascopopiene, cu vise eliberatoare și dese reîntoarceri acasă, Slavco Almăjan și-a creat în timp un fel de a fi care dă noblețe culturii și literaturii. „Înainte de a fi autorul spectacolului poetic, dominat de visul eliberator, Slavco Almăjan este un scriitor al amintirii: al repetatelor întoarceri acasă" (Ungureanu, 2015: 592). O serie de poeme îi

meleagurile bănățene care a ridicat vocea împotriva dogmatismului infect şi degradant" (Almăjan, 2007: 9).

${ }_{3}$ Printre nămeții Nordului este titlul volumului de poeme, care a apărut în anul 2012, la editura Ars Longa din Iași, cu o prefață de Christian Tămaș. 
conferă această poziție (Balada intrării în oraș, Poarta zăpezii, Dezlegarea izvoarelor...), precum și volumul de proză poetică Pianul cu păianjeni (1991). Din vasta creație a acestui senior al rostirii românești, cunoscut prin traduceri și în alte spații culturale, amintim în acest loc una dintre poeziile sale emblematice Ningea odată în Banat, pe care autorul a transformat-o în 2005 într-o carte adevărată, menită să reînvie motivele de-acasă și universul amintirilor. Această poezie a apărut pentru prima dată în volumul Liman trei (1978), în urma căruia poetul a devenit, în viziunea criticului literar Dan Cristea, „un moralist al evenimentelor sufletești” (Cristea, 1998:10-11). Spre sfârșitul secolului, în revista „Lumina” a apărut și o versiune a poeziei, ușor revăzută de poet ${ }^{4}$. Poemul Ningea odată în Banat emană o aromă de veșnicie exprimată printr-o rostire tandră, care poartă pașii celui care o aude spre o altă lume, departe de cea cotidiană, acolo unde s-a născut amintirea poetului rătăcitor printre ninsorile copilăriei și iubirile pure. „A căzut o aripă / Din privirea mea lungită/ Pe frunze aburite și obosite/ Și din aripă amintirea a ieșit și m-a alintat/ De atunci a început să ningă-n mine/ Cum ningea odată în Banat" (Almăjan, 2015: 25). Transpunerea în vers a ninsorilor din Banat nu este întâmplătoare, mărturisirea autorului este sinceră și îndeajuns de lămuritoare: „Iluzia fondatoare a zăpezii apare în poeziile mele de mai multe ori. Ea nu este incidentală, nici ocazională. Zăpada este substanța care mă caută, îmi sugerează, își propune să mă acompanieze, este materia care mă încurajează să accept scopul alternativ." (Almăjan, 2015: 45). În versuri, se trezesc la viață, alături de sentimentele curate, și imagini pământene inedite, conturate de alintul visului și al amintirii: „Deschide astă seară fereastra neadormită/ Vei vedea un nor cu fulgi liliachii/ Copacii-n strada noastră se vor legăna ritmat/ Se va mira lumea și vântul dezechilibrat/ Iar numai tu vei ști că ninge/ Cum ningea odată în Banat" (Almăjan, 2015: 25). Într-o iarnă lividă „Fantasticul coboară din ceruri și din vise/ $\mathrm{Cu}$ sunete și foc nedescifrat" (Almăjan, 2015: 25) și poposește între anotimpurile uitate, în timp ce vremurile albe înveșmântate în aura iubirii rămân în sanctuarul amintirilor: „Tu treci și atingi poarta de lemn/ Te-ntâmpină târziul precum o mărturie/ Alunecând spre orizontul argintat/ Și iar ceva vibrează și se transformă-n semn/ Deși azi nu mai ninge/ Cum ningea odată în Banat" (Almăjan, 2015: 25).

Ioan Flora (1950- 2005), poet și traducător, și-a făcut debutul literar în anul 1970 (la Editura „Libertatea” din Panciova) cu volumul de versuri Valsuri. A fost unul dintre promotorii clocotrismului belgrădean, atașându-se „simpatetic în cele din urmă de generația lui Mircea Cărtărescu” (Agache, 2010: 219), mișcare neo-avangardistă în care au participat scriitori de renume mondial (Mark Strand, Alan Ginsberg, Žerom Rotenberg, Hans Magnus

\footnotetext{
${ }^{4}$ Este vorba de revista „Lumina”, nr. 4, 1998, pp. 10-11.
} 
Enzensberger). Clocotrismul reprezintă un moment foarte important în colaborarea literară a celor două țări, Serbia și România, detectând începuturile post-modernismului în ambele țări. Prin clocotrism s-a încercat a se atrage atenția întregii lumi la contribuția culturii est-europene, iar din analiza relațiilor existente între poeții din cele două țări că valorile artistice trebuie privite nu numai în context istoric, ci și în cadrul coordonatelor axiologice sincronice. Se descoperă astfel un model cultural, care se definește ca reprezentativ pentru această regiune europeană, un exemplu de colaborare culturală reușită în Balcani. Din punct de vedere neo-avangardist, clocotrismul descoperă pentru prima dată faptul că, dacă artiștii români nu au avut voie să creeze o astfel de mișcare în timpul comunismului din România, ei au participat bucuroși în diferite „situacții” clocotriste la Belgrad, lăsândune importante manuscrise și desene. Trebuie menționaţi scriitorul Geo Bogza, care a participat și în avangarda românească din prima jumătate a sec. XX, Nichita Stănescu, Marin Sorescu, Petre Stoica și alții. Majoritatea volumelor de referință ale lui Ioan Flora au apărut în spațiul literar românesc din Voivodina $^{6}$, iar din anul 1993 s-a stabilit la București, în mediul poetic în care s-a și format. Într-un interviu, Ioan Flora spune despre poezia română din Voivodina următoarele:

„Poezia română scrisă în Banatul de dincolo de Prut este, la nivelul expresiei, mai directă, mai incisivă, mai scuturată de podoabe, mai frustă decât poezia confraților lor din Moldova, să zicem; e mai «actuală», mai lipsită de prejudecăți și mai nonconformistă, la nivel tematic. Cred că sunt câteva nume ce trebuie luate în seamă de fiecare dată când se alcătuiește în țară un dicționar, o antologie sau (de ce nu?!) un manual consacrat literaturii române contemporane, ale căror scrieri pot fi asemuite cu o buclă de mistreț în cosița diafană a poeziei unor poeți consacrați de la noi.” (Flora în Alexandrescu, 2001).

\footnotetext{
${ }^{5}$ Situacțiile (situație + acțiune) clocotriste sunt niște happening-uri care se desfăşoară în locuri publice. Participanții sunt numiți situactori și ei „exprimă fizic, cu ajutorul corpurilor lor, o rețea de relații, care sunt de obicei imaginate de artiști sau de oameni obișnuiți, chiar dacă extrapolarea lor fizică poate adesea părea amunzantă, grotescă...” (Dan, 2009: 66).

${ }^{6}$ Valsuri (1970), Iedera (1975), Fișe poetice (1977), Lumea fizică (1977), Terapia Muncii (1981), O bufniță tânără pe patul morții (1988), Tălpile violete (1990). Medeea și mașinile ei de război (1999). Cu excepția volumului Lumea fizică, care a apărut la Comuna literară Vârșeț (KOV), restul volumelor amintite mai sus au văzut lumina tiparului la Editura „Libertatea” din Panciova. În România au fost republicate volumele: Fişe poetice (1981), O bufniță tânără pe patul morții (1998), Starea de fapt (1986), Tălpile violete (1998). Doar în România au apărut: antologia Poeme (1993), Discurs asupra Struțocămilei (1995 şi 1998), Cincizeci de romane şi alte utopii/Fifty Novels and Other Utopias (1996), Iepurele suedez (1998), Dejun sub iarbă (2004) și volumele postum Intrarea în casă (Brumar, Timişoara, 2006), o antologie a poemelor bănățene (a fost pregătit de poetul și Bătrînul Werther, 2007, Editura Paralela 45).
} 
Poetul și-a construit traseul liric încercând tot felul de modernisme, cristalizându-și apoi propriile atitudini artistice. „Ioan Flora rămâne un poet baroc, un gânditor baroc, interesat de realismul magic, de alchimie, de eroii sau eroinele autodistrugerii” (Ungureanu, 2015: 611).

Poezia Banatului, ca de altfel și a lumii balcanice, se leagă de realitatea în care poetul nu se mai adaptează, reflectând o sensibilitate antiidilică hrănită din lipsa frumosului. $\mathrm{O}$ astfel de privire se definește chiar și atunci când este îndreptată spre copilărie: „Săteni avuți dar calici, ciorbă cu grăsime de două degete/ deasupra/ clisă și răchie îndulcită,/ îi fură somnul cu hățurile-n mână./ (Copilărie) (Flora în Baba, 2017: 222). Așezându-se între ai săi cu mânecile suflecate, poetul își revarsă aceleași sentimente de aversiune, atunci când e vorba de efortul truditorilor gliei. Sunt demne de citare versurile poeziei Cântec de vară:

„Descărcăm sacii de porumb o după-amiază/ întreagă./ Dar e o plăcere,/ Pământ negru îmi intră sub unghii;/ căldură, vomit./ Dar, e mai mult decât o plăcere./ Argilă, prund, moloz,/ se astupă fântâna din colț./ E mai mult decât ai îngropa omul de viu./ Porumb, vară violentă./ Trenul de patru, gustul de sudoare în gură,/ nu i te poți sustrage./ Descărcăm porumbul, 73 de saci” (Flora în Baba, 2017: 222-223).

Peisajul realului dur nu poate fi luminat nici de chipurile celor dragi, care evoluează sub cupola tristeții iremediabile:

„Duminică, 27 octombrie. Aseară am venit să-1 văd pe tata/ (neras, obosit, irascibil, singur)./ Seninul, senin, încât ai putea întrezări/ până și Semenicul./ În curte, prin pardoseaua de cărămizi verzui,/ suie la cer urzicile, viaţa stearpă./ ... Duminică, tihnă și soare./ Mama e fum surpat în pământ" (Fum surpat în pământ) (Flora în Baba, 2017: 225).

„Simfonia spațiului bănățean” (Popović, 2013: 70) își răspândește ecourile până când poetul își întrerupe rostirea. Din ultimul său volum, Dejun sub iarbă (2004), transcriem încă o secvență care se bucură de situarea în siajul reperelor semnificative pentru acest demers:

„În fiecare an, de Sfânta Maria Mare, mătușa mea Sofrana/ își aduna familia și neamurile, tăia câte o gâscă, un curcan/ pentru zupa mare, frământa aluaturi/ de cu noapte, pentru a ajunge la slujbă, în zori./ Mătușa Sofana era o femeie împlinită și nu se omora/ să se prindă în horă, dar îi sălta inima/ (de bucurie? De jind?)/ Când se pomenea să cânte în curtea bisericii fanfara/ (și mai ales Lae Puric, la taragotă)/ 
nesfârșite doine, și ardelene, și învârtite.// Se-mbrăca numai în straie nemțești, avea ochii mari albaștri/ și carnea albă și deasă și nu seaştepta nici în ruptul capului/ ca tocmai atunci, de hram Doamna aceea cu coasă și cutie la brâu/ să-i bată cu putere, tocmai ei la poartă" (Flora în Baba, 2017: 224-225).

În opinia criticului literar Mariana Dan, poveștile adevărate ale lui Ioan Flora redeschid, în lumea profană de azi, funcția soteriologică a artei prin epifanie și catharsis. Poemele sunt scrise așa cum ai „construi o casă /.../, iar cuvintele funcționează pe post de cărămizi. $\mathrm{Cu}$ ajutorul acestei metode au luat naștere adevărate opere de artă, a căror viziune e stabilită în cadrul logicii imanente a textului, nefiind nici expresia suprarealismului, nici a verismului, așa cum a fost etichetată uneori” (Dan, 2009: 70). Mai întâi, poezia lirică bănățeană devine un loc de întâlnire cu cotiturile esențiale ale limbajului poetic modern ca după două decenii să apară noi conștiințe poetice, deschizătoare de drumuri și capabile să exercite o mare influență asupra experiențelor poetice de viitor; poezia anilor șaptezeci ai secolului trecut abordează din mai multe unghiuri lumea satului bănățean, cu toată problematica complexă a vieții minoritarului român, a conglomeratului de naționalități în care trăiește, când apare un sat de tip sămănătorist, ideal, autentic, tradițional, arhaic și idealizat, de un primitivism naiv și fermecător, în care omul e legat organic de natură, de pământul care-l face structural bun și-i conservă respectul pentru valorile morale. Pe de altă parte, orașul, demonizat, nu e decât un spațiu corupător și alienant, în care cel plecat din sat, înstrăinații noștri poeți, rupți de energiile pământului străbun, de satul lor natal, sunt condamnați la nostalgie și suferință.

Poezia anilor optzeci și nouăzeci cunoaște ieșirea din spațiul bănățean și aprecierea moștenirii culturale în context european. În această perioadă versul scoate la iveală sentimentul dezrădăcinării care produce teamă, neîncredere și incapacitatea de a se adapta la noua cultură, la un alt spațiu, diferit de meleagurile bănățene.

Poezia despre Banat ori „cântecul de dor despre o țară”, cum a definit-o poetul Ioan Baba, reprezintă un capitol semnificativ în literatura română din Voivodina, care urcă în timp cu evoluția fiecărei etape literare. În articolul de față se relevă doar câteva însemne ale acestei îndeletniciri scriitoricești, care se exprimă prin formule, stiluri artistice diverse și în vremuri diferite. Adeseori, versurile dedicate Banatului conferă o adevărată valoare documentară, conturând imaginile unei lumi dispărute, cu oamenii, obiceiurile și tradițiile ei. Putem constata astfel că predilecția pentru aceste teme în poezia despre Banat scrisă în cea de-a doua jumătate a secolului trecut contribuie într-un mod decisiv la conturarea unui specific al literaturii 
române din Voivodina, prin atenția deosebită acordată acestui spațiu, devenit topos literar recurent.

\section{Referințe:}

Alexandrescu, R. (2001). Mă simt într-un anume fel optzecist. Interviu cu Ioan Flora/ I feel a certain eighties. Interview with Ioan Flora. În „Observator cultural", nr. 51, 13 februarie. Disponibil pe: https://www.observatorcultural.ro/articol/ma-simt-intr-un-anume-feloptzecist-interviu-cu-ioan-flora. Accesat la 08.05.2021.

Almăjan, S. (2015). Ningea odată în Banat/ It Was Snowing Once Banat. Panciova: Editura Libertatea.

Almăjan, S. (2007). Poezia de dincolo de cărți/ Poetry beyond books. În Libertatea, anul LXI, nr. 18 (3327), 9.

Agache, C. (2010). Literatura română din Voivodina/ Romanan Literature from Vojvodina. Panciova: Editura Libertatea.

Baba, I. (2006). Banatul și „Memoria clipei”/ Banat and "Memory of the moment”. În Lumina, anul LIX, Serie nouă, nr. 1, 1995-2005, 17.

Baba, I. (2017). Banatul în Memoria clipei - almanah panoramic al liricii româneștil Banat in Memory of the Moment - Panoramic Almanac of Romanian Lyric Poetry. Panciova: Editura Libertatea.

Balan, I. (2012). Caisul solitar. Versuri și proză/ The lonely apricot/ Lyrics and prose. Zrenianin: Editura ICRV.

Cioculescu, Ș. (1984). Cuvânt înainte. În Miloș I. (1984). Nunți boreale/ Boreal weddings. București: Editura Cartea Românească.

Copcea, F. (2020), Prefațăl Preface. În Almăjan, S. (2020). O sută și una de poeziil One Hundred and One Poems. București: Editura Academiei Române, 5.

Cristea, D. (1998). Despre poezia lui Slavco Almăjan/ About the Poetry of Slavco Almăjan. În Lumina, nr. 4, 10-11.

Dan, M. (2015). Ioan Flora - 10 ani de postumitate/ Ioan Flora - 10 Years of Posthumous. În Caiete critice, 3 (329), 65-79.

Dan, M. (2009). Biografie și creație în clocotrism/ Biography and Creation in Clocotrism. In Romanoslavica, XLIV, București: Editura Universității din București, 63-76.

Juică, B. (2012). Literatura română din Voivodina (1945-1989) - La confluența a două culturi/ Romanian Literature in Vojvodina (1945-1989) - At the Confluence of Two Cultures. Zrenianin: Editura ICRV.

Lăzăreanu, S. \& Păun, O. (1995). Intrarea în casă. Antologia poeziei românești din Iugoslavial Entrance to the House. Anthology of Romanian Poetry from Yugoslavia. București: Editura Fundației Culturale Române.

Miloș, I. (2012). Printre nămeții Nordului/ Among the snowy of The North. Iași: Ars Longa.

Popović, V. (2013). Opinii și reflecții. Lirica românească din Voivodina, I/ Opinions and reflections. Romanian Lyrics from Vojvodina, I. Panciova: Editura Libertatea. 
Popović, V. (2017). Ioan Baba, Banatul in memoria clipeil Ioan Baba, The Banat in memory of the moment. In Studii de Știință și Cultură, Volumul XIII, Numarul 3 (50), 137-140. Panciova: Editura Libertatea.

Popović, V. (2019). Particularități privind dezvoltarea literaturii române din Voivodina. Poezia și prozal Particularities regarding the development of Romanian literature in Vojvodina. Poetry and prose. In Studii de Știință și Cultură, Volumul XV, nr. 1, 105-111. Arad: „Vasile Goldiș” University Press

Popa, Șt.N. (1997). O istorie a literaturii române din Voivodinal A history of Romanian literature in Vojvodina. Panciova: Editura Libertatea.

Ungureanu, C. (2005). Geografia literaturii române azi, vol. 4 - Banatul/ Geography of Romanian literature today, vol. 4 - Banatul. Pitești: Paralela 45.

Ungureanu, C. (2015). Literatura Banatului - Istorie, personalități, contexte/ Banat Literature - History, personalities, contexts. Timișoara: Editura Brumar.

Uzelac, M. (1985). Rostirea intreruptă - douăsprezece interpretări din poezia lui Ion Bălan/ The interrupted utterance - twelve interpretations of Ion Bălan's poetry. Panciova: Editura Libertatea. 